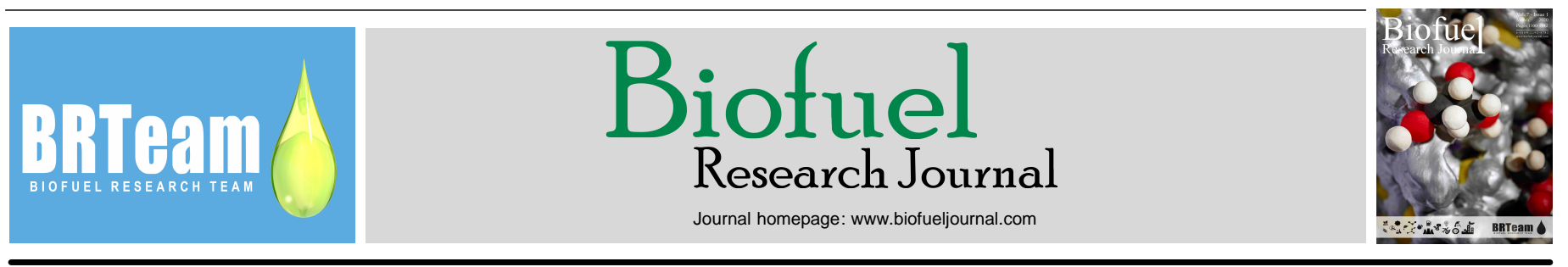

Review Paper

\title{
Pretreatment methods for lignocellulosic biofuels production: current advances, challenges and future prospects
}

Wai Yan Cheah ${ }^{1}$, Revathy Sankaran ${ }^{2}$, Pau Loke Show ${ }^{3, *}$, Tg. Nilam Baizura Tg. Ibrahim ${ }^{1,2}$, Kit Wayne Chew ${ }^{4}$, Alvin Culaba $^{5,6}$, Jo-Shu Chang ${ }^{7,8,9, *}$

${ }^{1}$ Department of Environmental Health, Faculty of Health Sciences, MAHSA University, 42610 Jenjarom, Selangor, Malaysia.

${ }^{2}$ Institute of Biological Sciences, Faculty of Science, University of Malaya, 50603, Kuala Lumpur, Malaysia.

${ }^{3}$ Department of Chemical and Environmental Engineering, Faculty of Science and Engineering, University of Nottingham Malaysia, Jalan Broga, 43500 Semenyih, Selangor Darul Ehsan, Malaysia.

${ }^{4}$ School of Mathematical Sciences, Faculty of Science and Engineering, University of Nottingham Malaysia, Jalan Broga, 43500 Semenyih, Selangor Darul Ehsan, Malaysia.

${ }^{5}$ Mechanical Engineering Department, De La Salle University, 2401 Taft Ave., Manila 0922, Philippines.

${ }^{6}$ Center for Engineering and Sustainable Development Research, De La Salle University, 2401 Taft Ave., Manila 0922, Philippines.

${ }^{7}$ Department of Chemical and Materials Engineering, College of Engineering, Tunghai University, Taichung 407, Taiwan.

${ }^{8}$ Center for Nanotechnology, Tunghai University, Taichung 407, Taiwan.

${ }^{9}$ Department Department of Chemical Engineering, National Cheng Kung University, Tainan 701, Taiwan.

\section{HIGHLIGHTS}

$>$ Recent advances on the pretreatment of lignocellulosic biomass are reviewed. $>$ Effects of pretreatment methods on lignocellulosic bioethanol production are critically compared. $>$ Challenges/perspectives of pretreatment technology for cellulosic biofuels are presented and discussed.

\section{GRAPHICAL ABSTRACT}

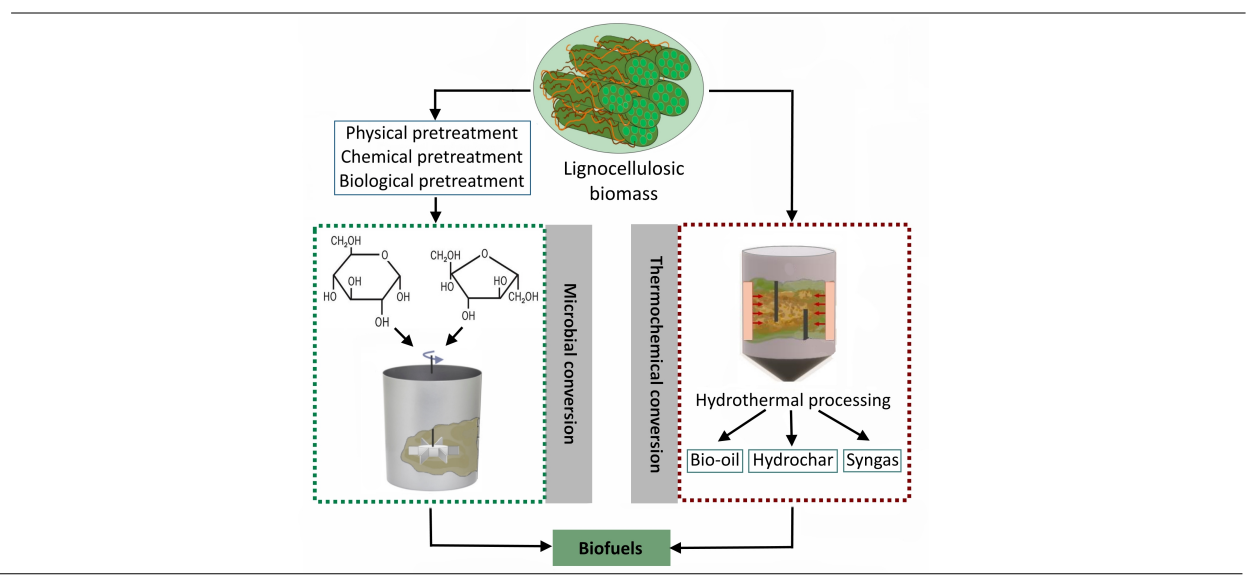

\section{ARTICLE INFO}

Received in revised form 22 January 2020

Accepted 26 January 2020

Available online 1 March 2020

\section{Keywords:}

Biomass

Biofuels

Pretreatment

Sustainability

Economic viability

\section{Article history:}

Received 7 December 2019

Lignocellulose

\section{ABSTRACT}

Lignocellulosic biomass has been recognized as promising feedstock for biofuels production. However, the high cost of pretreatment is one of the major challenges hindering large-scale production of biofuels from these abundant, indigenouslyavailable, and economic feedstock. In addition to high capital and operation cost, high water consumption is also regarded as a challenge unfavorably affecting the pretreatment performance. In the present review, advances in lignocellulose pretreatment technologies for biofuels production are reviewed and critically discussed. Moreover, the challenges faced and future research needs are addressed especially in optimization of operating parameters and assessment of total cost of biofuel production from lignocellulose biomass at large scale by using different pretreatment methods. Such information would pave the way for industrial-scale lignocellulosic biofuels production. Overall, it is important to ensure that throughout lignocellulosic bioethanol production processes, favorable features such as maximal energy saving, waste recycling, wastewater recycling, recovery of materials, and biorefinery approach are considered.

(C) 2020 BRTeam. All rights reserved.

* Corresponding author at: Tel.: +886 926585214 (J-S Chang) \& +60 389248605 (P.L. Show)

E-mail address: changjs@ mail.ncku.edu.tw (J-S Chang) \& PauLoke.Show@nottingham.edu.my (P.L. Show)

Please cite this article as: Cheah W.Y., Sankaran R., Show P.L., Tg. Ibrahim T.N.B., Chew K.W., Culaba A., Chang J-S. Pretreatment methods for lignocellulosic biofuels production: current advances, challenges and future prospects. Biofuel Research Journal 25 (2020) 1115-1127. DOI: 10.18331/BRJ2020.7.1.4 


\section{Contents}

1. Introduction.

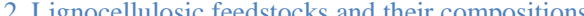

2. Agricultural residues and municipal solid waste.....

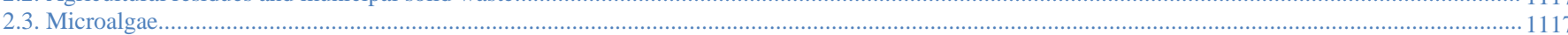

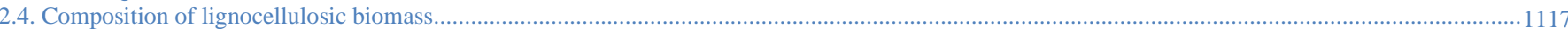

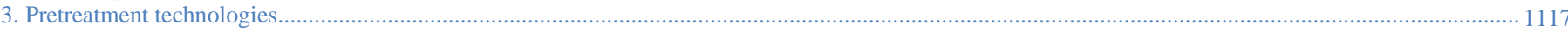

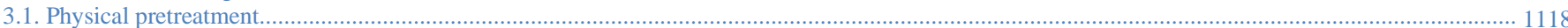

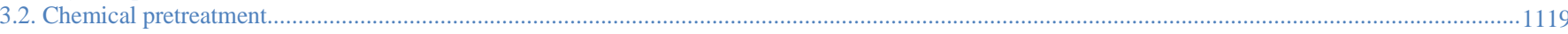

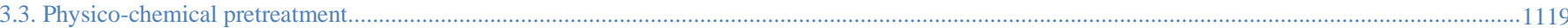

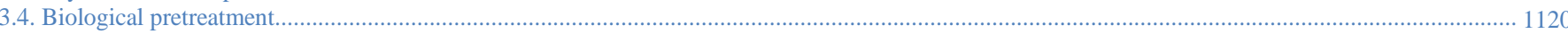

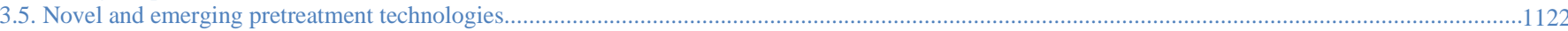

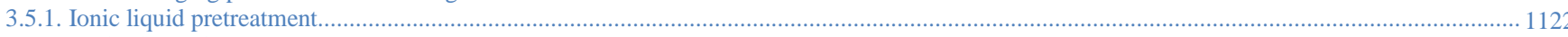

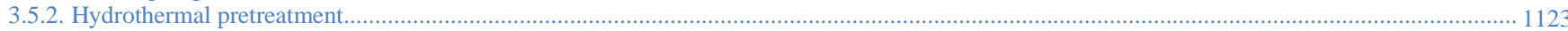

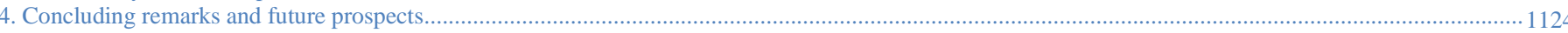

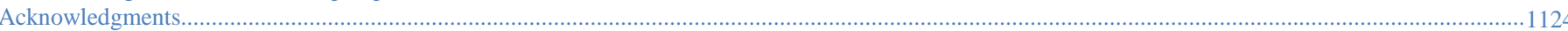

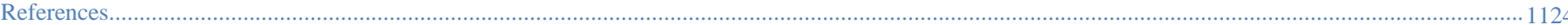

\section{Introduction}

The increasing global demands for fossil fuels and their widespread consumption, leading to environmental degradation, have been of major concerns. More specifically, the world-wide energy consumption is estimated to increase by $49 \%$ from 2007 to 2035 , alongside the growth in economy, expanding population, and social pressure (Cheah et al., 2016a; Prasad et al., 2016). India and China account for a major proportion of this drastic increase (Kumar et al., 2019). Energy security and environmental sustainability have put forward the need for developing alternative energy resources, to substitute fossil fuels. The alternatives for gasoline include bioethanol recognized as the most promising biofuel as it can be applied as sole fuel in compatible car engines or be blend up to $30 \%$ with gasoline without car engine modifications (Safarian and Unnthorsson, 2018). Bioethanol possesses high oxygen content resulting in better combustion efficiency while it also has a higher octane number allowing engine operation at high compression ratios (Branco et al., 2019). Bioethanol could be derived from corn, sugarcane, grains, and sugar beets. Brazil and the USA together contribute approximately $90 \%$ of global bioethanol production; 59\% and 27\%, respectively (Branco et al., 2019; Tran et al., 2019). Brazil`s annual bioethanol production from sugarcane stands at around 15 billion $\mathrm{L}$ while the USA annual bioethanol production of around 7 billion L is dependent on corn starch (Devarapalli et al., 2015; Tran et al., 2019; Rosales-Calsderon and Arantes, 2019). The considerably huge production rate of the USA is driven by the Policy Energy Act and Energy Independence and Security Act targeting bioethanol consumption of 136 billion gallons by 2022 (Menon and Rao, 2012; Tran et al., 2019).

Unfortunately, the production of bioethanol from the above-mentioned edible energy crops has endangered the global food security. Lignocellulosic biomass like agriculture residues, forest woody residues, microalgae, and even municipal solid waste, are therefore more favorable sources for bioethanol production. Lignocellulosic complex structure consists of cellulose, hemicellulose, and lignin. Cellulose is a polymer composed of glucose and provides structural support to plants, whereas hemicellulose is responsible for binding and lignin ensures the robustness of the whole stricture (Kumar et al., 2016; Prasad et al., 2016). Such feedstocks therefore, require labor-intensive and costly pretreatments prior to hydrolysis, fermentation, and distillation. Pretreatment is in fact an important step to (i) increase the amorphous region to ease hydrolysis (ii) enhance the porosity of porous matrix to ease chemical and enzymatic hydrolysis, and (iii) liberate cellulose from the lignin and hemicellulose (Tran et al., 2019). The most effective pretreatment methods applied at present, are mostly physico-chemical and chemical methods, which also result in the formation of toxic substances like furfural (Liyamen and Ricke, 2012). Other methods are also employed having their own pros and cons; for instance, biological pretreatment is eco-friendly but does not produce high yields. Thermochemical conversion using heat is also used to convert biomass into syngas, which can be further transformed into ethanol using catalysts (Mu et al. 2010).

Life cycle assessment (LCA) has been used a promising tool to assess the environmental impacts associated with the entire life cycle of bioethanol production including the pretreatment stage to clarify on environmental tradeoffs (Mu et al., 2010). For instance, LCA was used to compare the corn-based and switch grass-based bioethanol and the results obtained showed that greenhouse gas emissions were $57 \%$ and $65 \%$ lower compared to fossil fuel, respectively (Mu et al., 2010). In a different LCA study, i was shown that for producing an equivalent amount of bioethanol, the performance of the biochemical conversion method was more environmentally friendly than the thermochemical route (Mu et al., 2010 Liyamen and Ricke, 2012; Kumar et al., 2019). From the economic perspective, since bioethanol yield is very dependent on the characteristics of lignocellulosic biomass source, therefore, pretreatment is considered as the costliest operation (Kumar et al., 2019). It should also be noted that the cost associated with the detoxification of toxic inhibitors (produced in response to the pretreatment method used) should also be added to the pretreatment cost (Liyamen and Ricke, 2012). Overall, an effective pretreatment should be both environmentally and economically sound. It is also important to ensure that throughout the lignocellulosic bioethanol production process, other favorable features such as maximal energy saving, waste recycling, wastewater recycling, recovery of materials, and biorefinery approach are considered (Kumar et al., 2019). Given the significance of the pretreatment stage, in the present review, the updates on pretreatment processes are summarized while the challenges faced are also presented and thoroughly discussed.

\section{Lignocellulosic feedstocks and their compositions}

\subsection{Forest woody and herbaceous biomass}

Forest woody biomass is known as the one of the most promising renewable bioethanol feedstocks since it offers carbon bio-sequestration offsetting the carbon dioxide produced during combustion processes Woody biomass is readily available during forest thinning and timber harvesting and given its high energy content and low-cost, it could be effectively used for bioethanol production (Zheng et al., 2014). Woody biomass accounts for about $30 \%$ of the biomass used in the USA annually to produce bio-based energies (Liang et al., 2017). The forest woody feedstocks used in the USA are generally Pinus contorta, Pseudotsuga menziesii, and Pinus ponderosa, which are rich in hemicellulose (18-33\%) and cellulose (39-55\%) (Liang et al., 2017). Almost 90\% of the dry weight of forest woody biomass is composed of lignin, hemicellulose, cellulose and pectin (Prasad et al., 2016). More specifically, the typical biomass consists of $30-60 \%$ cellulose, $15-40 \%$ hemicellulose, and $10-25 \%$ of lignin (Liyamen and Ricke, 2012; Menon and Rao, 2012; Rosales-Calderon and Arantes, 2019).

Plants under the genus Populus with 35 species are the most abundant and fast-growing woody feedstock for bioethanol production (Liyamen and Ricke, 2012). Forest woody biomass was reported to generate less ash than agriculture residues, as the former possess more lignin and is of higher density (Liyamen and Ricke, 2012). Moreover, forest woody biomass offers 
a more flexible biomass harvesting time compared to agriculture residues. The forest residues like dead fronts, wood chips, and sawmills could also serve as bioethanol feedstock. Switchgrass is a well-known feedstock which could provide high yields of glucose, it is highly resistant against diseases, and has a high biomass productivity. Fast-growing high-yielding grass Miscanthus giganteus is another candidate for biofuel production. It is native to Asia but it is also grown in the Europe. This grass accounts for $50-70 \%$ of total biomass feedstock (including forest woody biomass and agriculture residues) used for cellulosic biofuel production (Liyamen and Ricke, 2012). It has been reported that $133 \times 10^{9} \mathrm{~L}$ of bioethanol could be generated by devoting $9.3 \%$ of the croplands in the USA to miscanthus cultivation, and through which one-fifth of the country`s gasoline consumption could be offset (Heaton et al., 2008). Scagline-Mellor et al. (2018) reported the cultivation of switchgrass and giant miscanthus on reclaimed mine sites in the eastern USA and claimed that the bioethanol yield was greater for miscanthus as compared to switchgrass.

\subsection{Agricultural residues and municipal solid waste}

Agriculture residues such as corn stalk, corn cobs, corn stover, sugarcane bagasse, rice stalk, and wheat stalk are potential sources for bioethanol production. These crops have a short-harvest rotation, thus allowing greater availability of these wastes throughout the year. About 350 to 450 million tonnes of crops are harvested annually and this generates huge quantities of agricultural waste (Liyamen and Ricke, 2012). For instance, wheat straw is produced during wheat grain harvesting at the rate of 1 to 3 tonnes/acre annually. One $\mathrm{kg}$ of corn stover would be generated against every single $\mathrm{kg}$ of corn grain harvested (Singh et al., 2018). Sarkar et al. (2012) claimed that a yearly bioethanol production of 418.9 Giga $L$ would be feasible from rice straw, wheat straw, corn straw, and sugarcane bagasse (Sarkar et al., 2012). Since agricultural residues offer a high level of availability and numerous harvesting cycles through only a single planting phase, the costs of managing these energy crops could be reduced. From the cost point of view, the price of sugarcane and corn stand at $60.9 \mathrm{USD} \$ /$ tonne and 185.9 USD\$/tonne, respectively, while those of sugarcane bagasse and corn stover stand at much lower values of only 36.4 and 58.5 USD\$/tonne, respectively (Rosales-Calderon and Arantes, 2019). It should be noted that approximately $70 \%$ of bioethanol production cost is associated with the cost of obtaining the feedstock, i.e., harvesting operation (Smuga-Kogut et al., 2019). A reduction in cost by half could be attained here by using agricultural residues, rather than the energy crops. More importantly, applying these wastes could contribute to a reduction in forest trees logging and the arable land used for herbaceous plants plantation like switchgrass, thus further promoting a greener environment.

Municipal solid waste and wastes from food and pulp industries have also been studied for ethanol production (Branco et al., 2019; Smuga-Kogut et al., 2019). Municipal solid waste is a promising feedstock as its carbohydrate content can be fermented for bioethanol production, while the protein and mineral fractions of the waste are also important to support the growth of fermenting microbes. Matsakas et al. (2014) has reported that through the application of dried household food waste, $43 \mathrm{~g} / \mathrm{L}$ of ethanol via enzymatic saccharification/liquefaction and fermentation could be produced. The remaining solid residues left after the fermentation process, were pretreated using microwave-assisted hydrothermal method, and were subsequently further fermented for a second round. A total yield of $59 \mathrm{~g} / \mathrm{L}$ of ethanol was produced after the two rounds of fermentation process.

\subsection{Microalgae}

Microalgae have been recognized over the last decades as promising feedstock for bioenergy production. Their carbohydrate content may be used to produce fermentative bioethanol and biobutanol, whereas their lipid content has a potential for biodiesel production. Gaseous biofuels like biomethane and biohydrogen can also be derived from microalgae or even their residues, after lipid extraction and ethanol fermentation (Cheah et al., 2016a). Microalgae species like Chlamydomonas sp., Chlorella sp., Spirulina sp., Spirogyra sp., and Dunaliella sp. are rich in carbohydrate content, with up to $64 \%$ of starch per dried cell weight, making them viable to serve as potential feedstock (Cheah et al., 2016a and b). Apart from this, microalgae possess high biomass productivity, high photosynthetic activity, and high $\mathrm{CO}_{2}$ biosequestration capabilities (Cheah et al., 2015). Unlike terrestrial plants, microalgae are lacking in lignin cross-linking structure enabling them to grow and float in seawater and wastewater, while producing higher amounts of sugar substrates for fermentation. Liyamen and Ricke (2012) claimed that microalgae produced 10 times more bioethanol than corn per area of cultivation. In recent years, engineering approaches have been incorporated into the microalgae cultivation systems, so as to produce microalgae biomass with greater carbohydrate contents, thus resulting in higher bioethanol yields. For instance, Chlamydomonas reinhardtii cultivated in a two-stage fed-batch photoautotrophic system exhibited $71 \%$ of carbohydrate content (Wang et al., 2015). Chlorella vulgaris JSC-6 grown under mixotrophic and nitrogen starvation conditions accumulated $54 \%$ of starch for acetone-biobutanol-bioethanol fermentation (Wang et al., 2016).

\subsection{Composition of lignocellulosic biomass}

Lignocellulosic feedstock is composed of cellulose, hemicellulose, and lignin. Cellulose is the most prevalent organic polymer that provides support to the plants as plant cell wall. It is also the main substrate used for fermentation. Cellulose is the polymer composed of D-glucose which is linked by $\beta-1,4$ glycosidic bonds. Several thousand glucose molecules are linked together by glycosidic bonds. Hemicellulose is the branched heteropolymer of hexoses (like D-glucose, D-galactose, and D-mannose), pentoses (like D-xylose and L-arabinose), and sugar acids (like Dglucuronic acid). Hemicellulose serves as the binding agent. Due to these varied sugars, a variety of enzymes is therefore required to hydrolyze these polymers into monomers (Liyamen and Ricke, 2012). Agricultural residues like rice straw and corn stover are comprised of mostly hemicellulose with lots of D-xylose. Lignin is an aromatic and rigid biopolymer with a high molecular weight. Cellulose and hemicellulose are tightly linked with lignin via covalent and hydrogenic bonds, making the biomass structure robust with high resistance towards biological and physical attacks. Efforts have been made to genetically modify lignin biosynthetic pathways in feedstock to improve bioethanol yields (Liyamen and Ricke, 2012). The compositions of lignocellulosic feedstock play a key role in the performance of biomass pretreatment and subsequently in the bioethanol production process. Table 1 shows the typical compositions of lignocellulosic biomass from various feedstocks.

Table 1.

Typical compositions of lignocellulosic biomass.

\begin{tabular}{lcccl}
\hline \multirow{2}{*}{ Feedstock } & \multicolumn{3}{c}{ Carbohydrate compositions (\%) } & \multirow{2}{*}{ References } \\
\cline { 2 - 5 } & Cellulose & Hemicellulose & Lignin & \\
\hline Sugarcane tops & 35 & 32 & 14 & Menon and Rao (2012) \\
Sugarcane bagasse & 42 & 25 & 20 & Kumar and Sharma (2017) \\
Corn stover & 38 & 26 & 19 & Kumar and Sharma (2017) \\
Corn cob & 45 & 35 & 15 & Kumar and Sharma (2017) \\
Rice straw & 38 & 32 & 12 & Baruah et al. (2018) \\
Rice husk & 37 & 29 & 24 & Baruah et al. (2018) \\
Wheat straw & $33-40$ & $20-25$ & $15-20$ & Baruah et al. (2018) \\
Switchgrass & $40-45$ & $30-35$ & 12 & Liyamen and Ricke (2012) \\
Leaves & $15-20$ & $80-85$ & 0 & Kumar and Sharma (2017) \\
Grass & $29-43$ & $8-29$ & $8-27$ & Smuga-Kogut et al. (2019) \\
$\begin{array}{l}\text { Agriculture } \\
\text { residues }\end{array}$ & $37-50$ & $25-50$ & $5-15$ & Liyamen and Ricke (2012) \\
$\begin{array}{l}\text { Industrial waste } \\
\text { from chemical pulp }\end{array}$ & $50-70$ & $12-20$ & $6-10$ & Liyamen and Ricke (2012) \\
Waste paper & 65 & 13 & 1 & Baruah et al. (2018) \\
\hline
\end{tabular}

\section{Pretreatment technologies}

Pretreatment is known as the most expensive processing step throughout the conversion of lignocellulosic biomass to fermentable sugars. This is ascribed to the costs of solids processing after pretreatment, liquid handling, as well as treatment of potentially present inhibitors and co-products. (Menon and Rao, 2012). Effective pretreatment, therefore, should be able to (i) enhance sugar yields for downstream processing, (ii) treat all types of 


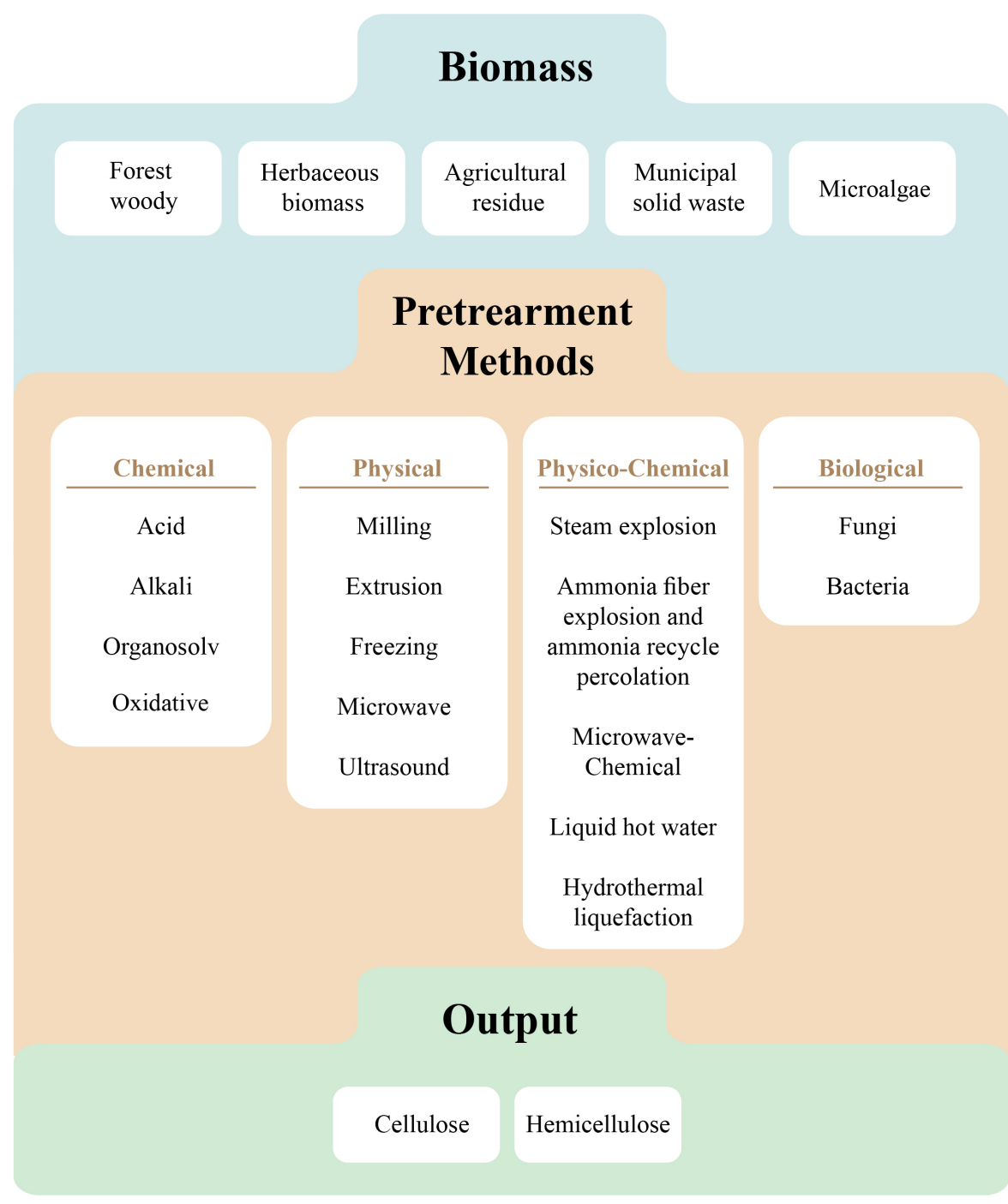

Fig. 1. Lignocellulosic biomass pretreatment methods.

lignocellulosic feedstock, (iii) assist in lignin recovery for subsequent combustion, (iv) lead to less formation of co-products or inhibitors, (v) minimize energy and operation costs, and (vi) regenerate valuable lignin coproducts (Prasad et al., 2016; Kumar and Sharma, 2017). There are various pretreatment options applied for bioethanol production. Figure 1 shows a summary of lignocellulosic biomass pretreatment methods. The choice of pretreatment methods relies on economic factor, the type of lignocellulosic feedstock, and its environmental impacts (Liyamen and Ricke, 2012; Menon and Rao 2012). Industrial inputs based on real-world situation are also important in enhancing pretreatment viability and eventually bioethanol production. The following sections describe the various pretreatment methods including their advantages and drawbacks based on recent findings.

\subsection{Physical pretreatment}

Physical or mechanical treatment such as milling, extrusion, freezing, ultrasound, and microwave irradiation, is applied on lignocellulosic biomass prior to the subsequent hydrolysis step. Improved hydrolysis outcomes and energy savings are attained by reduction of crystallinity and provide easy access for the enzymes and solvents. Physical pretreatment like extrusion is a recognized method used to produce char and gaseous product. Lignocellulosic biomass is treated at temperatures more than $300^{\circ} \mathrm{C}$ with a combination of shearing and mixing to remove and shorten biomass fibers (Maurya et al. 2015). Zheng et al. (2014) studied the application of modified twin screw extruder combined with filtration to remove xylose from steam exploded corncobs at $205^{\circ} \mathrm{C}$ (Zheng et al., 2014). The extrusion step resulted in structural changes and increases in glucose from $41 \%$ to $66 \%$ and $58 \%$, depending on varied extrusion conditions. Optimization strategies of physical pretreatment include adjustments of temperature, screw speed, and cellulose concentration. In another study, the pretreatment of switchgrass, blue stem, and prairie cord grass was performed at varied speeds, temperatures, and cellulose concentrations (Karunanithy et al., 2012). The best results obtained were about $28 \%, 66 \%$, and $49 \%$ glucose from switchgrass, blue stem, and prairie cord grass pretreated at $75^{\circ} \mathrm{C}, 150^{\circ} \mathrm{C}$ and $100^{\circ} \mathrm{C}$ with the screw speed of $200 \mathrm{rpm}, 200 \mathrm{rpm}$, and $150 \mathrm{rpm}$, respectively (Karunanithy et al., 2012). This pretreatment method is difficult to scale up for commercial purposes as it incurs high amounts of operation and energy cost. Overall, the physical pretreatment cost is expensive and its energy consumption could be higher than energy content of the biomass (Menon and Rao, 2012).

Milling is another commonly applied method to pretreat biomass, so as to increase the specific surface area for enzymatic hydrolysis, increase the degree of polymerization, and reduce cellulose crystallinity. Milling can reduce the particle size down to $0.2 \mathrm{~mm}$ (Baruah et al., 2018). Smaller size of lignocellulosic biomass provides greater surface area. It is also known as 
best suited method for both ethanol and methane production, with no inhibitor generated. Ball mills, attrition mills, centrifugal mills, colloid mills, hammer mills, vibratory mills, pin mills, and extruder are commonly applied (Amin et al., 2017). Palm oil biomass like empty fruit bunch and dead frond fiber were pretreated using ball milling method. Maximal glucose (87\%) and xylose $(\sim 82 \%)$ were obtained from the pretreated oil palm frond fiber (Zakaria et al., 2014). Gu et al. (2018) reported on planetary ball milling of post-harvest forest residues, yielding the maximal glucose and xylose/mannose of $59.67 \%$ and $23.83 \%$, respectively, with low energy input ranging between $0.20-2.15$ $\mathrm{kWh} / \mathrm{kg}$ for 7 to $30 \mathrm{~min}$ of milling. The parameters to be considered for effective milling operation include feeding rate of biomass, initial biomass size, machinery parameters, time, and moisture content (Amin et al., 2017; Jędrzejczyk et al., 2019).

Lignocellulosic biomass can be pretreated using the freezing method via volumetric change of water. The volume of water changes as it transforms from liquid to solid at low temperatures. As water diffuses into biomass, the volume of water increases during freezing, resulting in breakdown of the cell walls (Rooni et al., 2017). This method is cheap and environmental-friendly without leading to the generation of inhibitors. Rooni et al. (2017) found out that four cycles of freezing at $-18^{\circ} \mathrm{C}$ and thawing at $22^{\circ} \mathrm{C}$, resulted in the highest glucose yield. Microwave-assisted pretreatment has also been found to be very effective in pretreating switchgrass and miscanthus (Jędrzejczyk et al., 2019). Microwave irradiations provide an easy operation, high heating capacity at short times, and no inhibitor is formed. Nevertheless, the duration of microwave is an important factor to be taken into account for effective pretreatment. A longer exposure time may lead to inhibitor generation and degradation of reducing sugars (Jedrzejczyk et al., 2019). Microwave is generally used in combination with chemical pretreatments for higher pretreatment efficiency.

Ultrasound-assisted pretreatment is another alternative for lignocellulosic biomass pretreatment via the concept of delignification and surface erosion. It offers short processing time, lower operating temperature, and less chemical usage. El Achkar et al. (2018) reported on enhanced biomethane production from grape pomace pretreated by using ultrasound at a frequency of $50 \mathrm{kHz}$, temperature of less than $25^{\circ} \mathrm{C}$ with a residence time of $40-70 \mathrm{~min}$. An enhancement was attained following the enhancement in the number of soluble ingredients after pretreatment. Overall, the pretreatment efficiency could vary depending on the solvent used, ultrasonic frequency, and reactor design (Bussemaker et al., 2013). Similar to the microwave-assisted method, this method is often used in combination with other technologies for more effective pretreatment.

\subsection{Chemical pretreatment}

Chemical pretreatment is the most applied method at commercial scale. It is commonly applied for cellulosic delignification in the pulping industry. Chemicals applied include acid, alkali, organic acids, $\mathrm{pH}$-controlled liquid hot water, and ionic liquids (green solvent). Sulphuric acid, nitric acid, phosphoric acid, and hydrochloric acid are typically used for pretreatment. The pretreatment process could be carried out at high temperatures $\left(>180^{\circ} \mathrm{C}\right)$ for 1 $5 \mathrm{~min}$, or mild temperatures $\left(<120^{\circ} \mathrm{C}\right)$ but at longer residence times $(30-90 \mathrm{~min})$ (Kumar \& Sharma 2017). This method could also be performed at low temperatures $\left(<100^{\circ} \mathrm{C}\right)$ for higher concentrations of acids $(30-70 \%)$ and at higher temperatures $\left(100-250^{\circ} \mathrm{C}\right)$ for dilute acids $(<10 \%)$ (Baruah et al., 2018). Dilute sulphuric acid is commonly applied to pretreat switchgrass and corn stover. About $0.2 \%$ to $2.5 \%(\mathrm{w} / \mathrm{w})$ is generally added into the biomass for pretreatment, at temperatures ranging between 130 to $210^{\circ} \mathrm{C}$ with continuous stirring (Menon and Rao, 2012). The main drawbacks of acid pretreatment include, 1) inhibitors generation which requires extensive washing or neutralization prior to fermentation and 2) corrosive nature of acid corroding reactors (Kumar and Sharma, 2017). Hydroxymethylofurfural and acetic acid formed during acid pretreatment (at a concentration of $2 \mathrm{~g} / \mathrm{L}$ and $3 \mathrm{~g} / \mathrm{L}$, respectively) have shown inhibitory effect on the subsequent fermentation (Jẹdrzejczyk et al., 2019).

Acid pretreatment works for hemicellulose removal while it can also be followed by alkali pretreatment to remove lignin, eventually resulting in pure cellulose. Alkali pretreatment involves the addition of hydroxide salts like sodium, potassium, calcium, and ammonium. Alkali application is able to alter the structure of lignin by degrading ester and glycosidic side chains, cellulose swelling, and partial cellulose recrystallization. Rice straw pretreated using aqueous ammonia and dilute sulphuric acid yielded $96.9 \%$ and $90.8 \%$ of lignin and hemicellulose removal, respectively (Kim et al., 2011). Calcium hydroxide is the most economic alkaline pretreatment when compared to ammonia, sodium hydroxide, and potassium hydroxide. Biogas yielded from corn cob residues was two times higher than untreated corn cob, as lime pretreatment accelerated the digestion process by removing lignin (Baruah et al., 2018). Optimization strategies like time and chemical concentrations are important factors to enhance the reaction rates.

Organosolv is a mixture of organic solvents capable of solubilizing hemicellulose and extracting lignin. The commonly used organic solvents used as catalyst for the organosolvation reaction are methanol, ethanol, acetone, ethylene glycol with organic acids like oxalic, salicylic, and acetylsalicylic (Jędrzejczyk et al., 2019). This technique results in delignification and complete solubilization of hemicellulose (Jẹdrzejczyk et al., 2019). The range of temperature applied is $100-250^{\circ} \mathrm{C}$. This pretreatment is indeed effective; however, its main concern is the cost and the chemical usage which requires a further step for solvent recycling. Another type of pretreatment is the oxidative pretreatment in which oxidative agents such as oxygen, ozone, hydrogen peroxide, and air are used. The oxidizing agent is applied to oxidize aromatic rings into carboxylic acids. The process in not selective, and therefore, loss of cellulose and hemicellulose could also occur following the delignification. Overall, this method is not common as it is energy and cost-consuming, and is thereby difficult to implement at large scale. Generation and handling of ozone gas is another concern associated with the application of this pretreatment.

\subsection{Physico-chemical pretreatment}

Lignocellulosic biomass can also be pretreated physically and chemically in combination. For instance, milling, a physical pretreatment, can be performed alongside alkali pretreatment to enhance pretreatment efficiency. In a study, the efficiency of enzymatic hydrolysis was increased by up to $110 \%$ by combined pretreatment of corn stover with the millingalkali method (Kumar and Sharma, 2017). Other examples of combined pretreatments are steam explosion, ammonia fiber explosion, ammonia recycle percolation, carbon dioxide explosive, microwave-chemical, and liquid hot water. Steam explosion applies high pressures of steam followed by sudden reduction of pressure, so as the biomass undergoes explosive decompression. This quick depressurization involves an initial temperature of 160 to $260^{\circ} \mathrm{C}$ for seconds and minutes in saturated steam prior to exposure to atmospheric pressure (Baruah et al., 2018; Kim, 2018). The method is known to be effective to disintegrate various lignocellulosic biomass feedstock, forest residues, and wastes at low cost and fast rate. Kim (2018) claimed that the steam explosion pretreatment uses 70\% less energy compared to physical pretreatments. During the steam pretreatment stage, hemicellulose is hydrolyzed and acids are formed in-situ, further hydrolyzing the hemicellulose.

The concept of the ammonia fiber explosion is almost similar to that of the steam explosion. Lignocellulosic biomass is exposed to ammonia at high pressures and temperatures, followed by sudden reduction of pressure. Approximately $1-2 \mathrm{~kg}$ of liquid ammonia is applied for every single $\mathrm{kg}$ of dried biomass. The temperature used would be $90^{\circ} \mathrm{C}$ for $30 \mathrm{~min}$ of residence time (Menon and Rao, 2012). Ammonia recycle percolation pretreatment is similar to ammonia fiber explosion. More specifically, aqueous ammonia (10-15\%) is applied on biomass at temperatures ranging between 150 to $170^{\circ} \mathrm{C}$ for $14 \mathrm{~min}$ (Menon and Rao, 2012). Both methods work to cleave C$\mathrm{O}-\mathrm{C}$ bonds in lignin and lignin-carbohydrate complex linkage; as well as to increase the surface area of biomass for more effective enzyme hydrolysis. This method is effective for biomasses like wheat straw, wheat chaff, and alfalfa but is not highly effective on woody lignocellulosic biomass. Nevertheless, the main concern associated with the application of this technique is the cost of ammonia and its recovery, increasing the overall cost of pretreatment.

Lignocellulosic biomass can also be pretreated by using the carbon dioxide explosive method where a combination of steam and supercritical $\mathrm{CO}_{2}\left(\mathrm{scCO}_{2}\right)$ is used. Due to the high pressure present, $\mathrm{CO}_{2}$ is explosively discharged through a nozzle, causing lignocellulosic biomass structure to rupture (Puri and Mamers, 1983; Lü et al., 2013). This method is considerably economic, non-toxic, and is known to reduce greenhouse 
effect due to the utilization of $\mathrm{CO}_{2}$. Liu et al. (2014) used this technique to pretreat corncob, cornstalk, and rice straw at 80 to $160^{\circ} \mathrm{C}, 5-20 \mathrm{MPa}$ for 15 to $60 \mathrm{~min}$. They argued that the pretreament was effective in improving the reducing sugar yields, with the best results obtained for corncob (Liu et al., 2014). Lü et al. (2013) successfully enhanced the efficiency of $\mathrm{scCO}_{2}$ pretreatment by the addition of co-solvents such as ethanol, butanol, and water.

Microwave-chemical pretreatment is performed by heating chemicals together with biomass using microwave. Miscanthus biomass was pretreated using microwave together with sodium hydroxide and sulphuric acid. As compared to pretreatment using alkali and acid alone, sugar yield was increased by 12 times while only half of the reaction time was required (Kumar and Sharma, 2017). Higher hydrolysis rate and glucose content in the hydrolysate were attained during the enzymatic hydrolysis stage of pretreated rice straw using microwave/acid/alkali/ $/ \mathrm{H}_{2} \mathrm{O}_{2}$ (Menon and Rao, 2012). Microwave with ionic liquid pretreatment of Crotalaria juncea at $160^{\circ} \mathrm{C}$ with $46 \mathrm{~min}$ of reaction time led to a glucose yield of $78.7 \%$ (Paul and Dutta, 2018). Microwave with acid pretreatment of Jabon kraft pulp produced $49 \%$ of reducing sugars at $190^{\circ} \mathrm{C}$ (Fatriasari et al., 2019). Liquid hot water pretreatment uses water at varied temperatures $\left(160-240^{\circ} \mathrm{C}\right)$ while high pressures are applied to maintain water in the liquid state (Kim, 2018). The method offers advantages like low cost as no chemical and catalyst is required, no inhibitor formation, no size reduction requirement prior to pretreatment, and ability to pretreat up to $80 \%$ of hemicellulose (Menon and Rao, 2012; Kim, 2018). It has been reported that xylose recovery of $80 \%$ and enzymatic hydrolysis of $91 \%$ could be achieved by pretreating wheat straw by using the liquid heat water method (Menon and Rao, 2012).

\subsection{Biological pretreatment}

The naturally found wide taxonomic array of microorganisms are used in biological pretreatment. Fungi and bacteria are capable of biologically pretreating lignocellulosic biomass by modifying its structure and degrading it into simpler substrates for ligninolytic enzyme digestion. Cellulose and hemicellulose are normally hydrolyzed in biologica pretreatment to monomeric sugars using cellulolytic and hemicellulolytic microorganisms (Sharma et al., 2017; Koupaie et al., 2019). White-rot, brown-rot, and soft-rot fungi are known to be effective microorganisms in pretreating biomass by producing lignin-degrading enzymes, while whiterot-fungi are more commonly used as they are able to provide higher sugar yields (Baruah et al., 2018; Waghmare et al., 2018). Lignin-degrading

Table 2.

Typical Comparisons of the strengths and weaknesses of the different pretreatment methods used for lignocellulosic biofuels production (Kumar et al., 2019; Menon et al., 2012, Jędrzejczyk et al. 2019).

\begin{tabular}{|c|c|c|c|c|c|}
\hline Pretreatment & Cost & Toxic by-product & $\begin{array}{l}\text { Applicable to a wide } \\
\text { range of biomass }\end{array}$ & Remarks & Enhancement of biofuel production \\
\hline Acid pretreatment & Low & High & Yes & $\begin{array}{l}\text { Dilute acid is used to limit inhibitors } \\
\text { generation }\end{array}$ & $\begin{array}{l}\text { Solubilization of hemicellulose; condensation and } \\
\text { precipitation of solubilized lignin. }\end{array}$ \\
\hline Freezing & Low & Low & No & Cycles of freezing and thawing & $\begin{array}{l}\text { Biomass cell walls are broken down due to volumetric } \\
\text { change of water from liquid to solid state }\end{array}$ \\
\hline Milling & Low & Low & Yes & $\begin{array}{l}\text { Used for bioethanol and biogas } \\
\text { generation }\end{array}$ & $\begin{array}{l}\text { Increases surface area for enzymatic hydrolysis, increases } \\
\text { the degree of polymerization, and reduces cellulose } \\
\text { crystallinity }\end{array}$ \\
\hline Liquid hot water & Low & Low & No & High water and energy inputs & $\begin{array}{l}\text { Improves enzymatic digestibility of biomass when in } \\
\text { contact with cellulase enzyme }\end{array}$ \\
\hline $\begin{array}{l}\text { Organic solvent } \\
\text { (Organosolv) }\end{array}$ & High & High & Yes & $\begin{array}{l}\text { Low boiling point of solvent. } \\
\text { Solvent recycling is required. }\end{array}$ & $\begin{array}{l}\text { Enhances enzymatic hydrolysis and saccharification by } \\
\text { breaking the internal bonds between lignin and } \\
\text { hemicellulose leaving pure cellulose residues. }\end{array}$ \\
\hline Oxidation & High & No & Yes & $\begin{array}{l}\text { High cost of ozone generation. } \\
\text { Proper ozone handling is required. }\end{array}$ & $\begin{array}{l}\text { Delignification by electrophilic substitution, displacement } \\
\text { of side chains, and cleavage of alkyl-aryl linkage }\end{array}$ \\
\hline Steam explosion & High & High & Yes & High cost of steam generation & $\begin{array}{l}\text { High temperature and pressure enhance the breakdown of } \\
\text { the glycosidic bonds in cellulose and hemicellulose as } \\
\text { well as the cleavage of hemicellulose-lignin bonds }\end{array}$ \\
\hline Extrusion & Low & Low & Yes & Hydrolysis efficiency is improved & $\begin{array}{l}\text { Increases enzymatic hydrolysis rates and provides better } \\
\text { controlling over all variables for improved biofuel } \\
\text { production }\end{array}$ \\
\hline Wet oxidation & High & Low & No & $\begin{array}{l}\text { Less water use as no solid washing is } \\
\text { required }\end{array}$ & $\begin{array}{l}\text { Provides a high degree of solubilization of hemicellulose } \\
\text { and lignin }\end{array}$ \\
\hline $\mathrm{CO}_{2}$ explosion & High & Low & Yes & High cost for pressure maintenance & $\begin{array}{l}\text { Increases accessible surface area, improves hydrolysis } \\
\text { process, and decreases the production of inhibitory } \\
\text { compounds }\end{array}$ \\
\hline Microwave irradiation & High & Low & Yes & $\begin{array}{l}\text { More effective than conventional heating } \\
\text { process }\end{array}$ & $\begin{array}{l}\text { High energy radiations able to disrupt chemical bonds in } \\
\text { biomass resulting in characteristics changes including } \\
\text { decreased cellulose crystallinity, depolymerization of } \\
\text { lignin, and hydrolysis of hemicelluloses }\end{array}$ \\
\hline Ultrasound & High & Low & Yes & Low temperature and less time required & Delignification and surface erosion \\
\hline $\begin{array}{l}\text { Ammonium fiber expansion } \\
\text { (APEX) }\end{array}$ & High & Low & Yes & $\begin{array}{l}\text { Less effective for biomass with high } \\
\text { lignin contents }\end{array}$ & $\begin{array}{l}\text { Increases accessible surface area and does not require } \\
\text { small particle size of biomass }\end{array}$ \\
\hline Ionic liquid (IL) & High & Low & Yes & $\begin{array}{l}\text { Stability and reuse of IL. Instability of } \\
\text { IL may cause contamination }\end{array}$ & Improves cellulose dissolution \\
\hline Biological pretreatment & Low & Low & Yes & Less cost but time consuming & $\begin{array}{l}\text { Increases delignification and able to reduce cellulose } \\
\text { polymerization }\end{array}$ \\
\hline Hydrothermal liquefaction & High & Low & Yes & $\begin{array}{l}\text { Lignocellulosic materials are } \\
\text { depolymerized into bio-oil, biogas, } \\
\text { biochar, and water-soluble compounds } \\
\text { in an aerobic or anaerobic enclosure. }\end{array}$ & $\begin{array}{l}\text { Cellulose is both accessible and susceptible to enzyme } \\
\text { hydrolysis }\end{array}$ \\
\hline
\end{tabular}

Please cite this article as: Cheah W.Y., Sankaran R., Show P.L., Tg. Ibrahim T.N.B., Chew K.W., Culaba A., Chang J-S. Pretreatment methods for lignocellulosic biofuels production: current advances, challenges and future prospects. Biofuel Research Journal 25 (2020) 1115-1127. DOI: 10.18331/BRJ2020.7.1.4 
enzymes include phenol oxidase, lignin peroxidase, versatile peroxidase, and manganese peroxidase. Simultaneous degradation and fermentation of lignocellulosic biomass by these microorganisms could lead to the formation of various biofuels (including ethanol, hydrogen, and methane) and biomaterials (such as various enzymes, lactates, acetates, and organic acids) (Sharma et al., 2017; Xu et al., 2017).

In addition to microorganisms such as bacteria and fungi, there are other organisms which could be used for biological pretreatment of biomass including insects (Varelas and Langton, 2017), worms (Devi et al., 2019), and gastropods (Trincone, 2018). Such macro-organisms are equipped with various mechanisms ranging from mechanical, enzymatic, gut flora and/or combo with certain physiological functions for the breakdown of cellulosic biomass. Such species have their own unique feeding/mastication system for physical deterioration and various enzymatic components for successful cellulose digestion. There are various taxonomic groups of insects known for digestion of cellulosic biomass including wood, leaf litters, and forage. The earthworms are well known for their detritus feeding behaviour. Most epizoic composting earthworms including Eisenia fetida, Perionyx excavates, Lumbricus rebellus, etc. could digest the organic matters efficiently (Yao et al., 2018).

The enzymatic activity within the gut of the earthworm followed by microbial flora activities has the ability to digest cellulose, carbohydrates, chitin, lignin, starch, etc. Hence, worm tea (i.e., vermicomposting liquid leachate) is used as an option for biological pretreatment. The microflora found in gastropods and ruminant mammals could also be used as sources of effective microbes to be used for cellulose digestion. There exist many reports on insolation of microbes from such environments and their implementation in biological pretreatment of lignocellulosic materials and the production of bioproducts (Vasco-Correa et al., 2016; Sharma et al., 2017).

Biological pretreatment could be influenced by various factors including physical factors (temperature, moisture, incubation time, aeration, subtract size, accessible surface area, etc.), chemical factors $(\mathrm{pH}$, culture media composition, carbon source, nitrogen source, cellulose crystallinity, inorganic and organic compounds, enzyme and hydrolysate roles, etc.) and biological factors (species of microorganisms, consortia of microorganisms, their interaction, and competition, etc.). These conditions alter the rate of biomass degradation and play major roles in altering the physiochemical structure of lignocellulosic biomass (Vasco-Correa et al. 2019). Overall, the benefits of biological pretreatment include low energy input, no chemical application, and working under mild environmenta

Table 3.

Pretreatment methods used on various lignocellulosic feedstocks and their performance attributes.

\begin{tabular}{|c|c|c|c|c|c|c|}
\hline Pretreatment & Feedstock & Water consumption & $\begin{array}{l}\text { Pretreatment energy } \\
\text { consumption }\end{array}$ & $\begin{array}{l}\text { Bioethanol production } \\
\text { (L/kg dried biomass) }\end{array}$ & $\begin{array}{l}\text { Cellulose/glucose } \\
\text { recovery }(\%)\end{array}$ & References \\
\hline Acid & Olive tree biomass & 21.89/L bioethanol & $2.34-5.83 \mathrm{MW}$ & $97,300-110,830$ & - & Solarto-Toro et al. (2019) \\
\hline Diluted acid & Corn stover & $389,560 \mathrm{~kg} / \mathrm{h}$ & $255.0 \mathrm{MW}$ & 5.85 & - & da Silva et al. (2016) \\
\hline Mild $\mathrm{NaOH}$ & Raw Cogon grass & $\begin{array}{c}46 \mathrm{~kg} / \mathrm{kg} \text { of dried } \\
\text { biomass }\end{array}$ & - & $0.134-0.174$ & - & Goshadrou (2019) \\
\hline $\mathrm{NaOH}$ & Banana pseudostem & - & - & - & 75.48 & Shimizu et al. (2018) \\
\hline Peroxide & Banana pseudostem & - & - & - & 74.37 & Shimizu et al. (2018) \\
\hline Ball milling & $\begin{array}{c}\text { Rice straw } \\
(2.5 \% \text { solid content })\end{array}$ & - & - & 116.65 & - & Zhang et al. (2018) \\
\hline Ball milling & $\begin{array}{c}\text { Rice straw } \\
\text { (10\% solid content })\end{array}$ & - & - & 147.42 & - & Zhang et al. (2018) \\
\hline Freezing & Barley straw & - & - & $0.042-0.054$ & 19.42 & Rooni et al. (2017) \\
\hline Ultrasound & Corn meal & - & - & $9.67 \pm 0.11$ & - & Nikolić et al. (2011) \\
\hline Microwave & Corn meal & - & - & $9.87 \pm 0.10$ & - & Nikolić et al. (2011) \\
\hline Liquid hot water & Palm oil residue & $\begin{array}{l}2.62-7.62 \mathrm{~kg} / \mathrm{kg} \text { of } \\
\text { dried biomass }\end{array}$ & $\begin{array}{c}2.90-16.52 \mathrm{MJ} / \mathrm{kg} \text { of } \\
\text { dried biomass }\end{array}$ & $109,600-172,100$ & - & Cardona et al. (2018) \\
\hline Liquid hot water & Corn stover & $470,237 \mathrm{~kg} / \mathrm{h}$ & $232.2 \mathrm{MW}$ & 5.20 & - & da Silva et al. (2016) \\
\hline Liquid hot water & Sugarcane & - & $\begin{array}{l}155 \mathrm{MW} \text { of total energy } \\
\text { consumption }\end{array}$ & 88,950 & - & Longati et al. (2018) \\
\hline Liquid hot water & Sugarcane & - & $\begin{array}{l}77.7 \mathrm{MW} \text { of total energy } \\
\text { consumption }\end{array}$ & 109,900 & - & Longati et al. (2018) \\
\hline Ammonia fiber explosion & Corn stover & $275,275 \mathrm{~kg} / \mathrm{h}$ & 345.4 MW & 5.40 & - & da Silva et al. (2016) \\
\hline Microwave-assisted organosolv & Mixed saw mill & - & $\begin{array}{c}12.5-19.0 \mathrm{MJ} / \mathrm{kg} \text { of dried } \\
\text { biomass }\end{array}$ & - & $98 \pm 2$ & Alio et al. (2019) \\
\hline Hydrothermal liquefaction & Eucalyptus & - & $26 \mathrm{MJ} / \mathrm{kg}$ of dried biomass & 0.612 & - & Wu et al. (2019) \\
\hline Supercritical $\mathrm{CO}_{2}$ & Corn stover & - & - & - & 77.8 & Lü et al. (2013) \\
\hline Saccharomyces cerevisiae & Paddy straw & - & - & 0.00086 & - & Arora et al. (2016) \\
\hline Escherichia coli FBR 5 & Corn stover & & & 0.0209 & & Zabed et al. (2016) \\
\hline S. cerevisiae SXA-R2P-E & Rice straw & & & 0.0207 & & Zabed et al. (2016) \\
\hline E. coli MS04 & Olive tree pruning & & & 0.023 & & Zabed et al. (2016) \\
\hline Phlebia brevispora & Corn stover & & & $36 \pm 0.6$ & & Saha et al. (2017) \\
\hline Trichoderma reesei & Palm wood & & & 0.0229 & & Sathendra et al. (2019) \\
\hline
\end{tabular}

Please cite this article as: Cheah W.Y., Sankaran R., Show P.L., Tg. Ibrahim T.N.B., Chew K.W., Culaba A., Chang J-S. Pretreatment methods for lignocellulosic biofuels production: current advances, challenges and future prospects. Biofuel Research Journal 25 (2020) 1115-1127. DOI: 10.18331/BRJ2020.7.1.4 


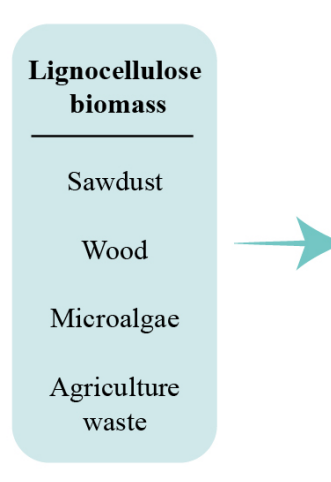

Ionic liquid pretreatment

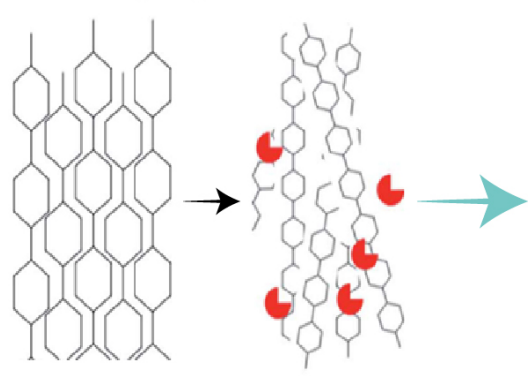

Modification of

lignocellulose biomass structure

Fig. 2. Method of ionic liquid pretreatment for lignocellulose biomass.

conditions while the drawbacks are being time-consuming and requiring close monitoring of growth conditions. In addition to these, lignin-consuming microorganisms also consume hemicellulose and cellulose. This challenge has made biological pretreatment of biomass, considerably less attractive commercially.

Table 2 compares various pretreatment methods in terms of their strengths and weaknesses while Table 3 tabulates the various performance features of these methods including bioethanol production, cost, toxic compounds production, as well as water and energy consumption. It should be noted that the findings summarized do not represent a strict comparison among pretreatment methods, as the yields correspond to different types of biomass feedstock and operating parameters.

\subsection{Novel and emerging pretreatment technologies}

\subsubsection{Ionic liquid pretreatment}

Recently, the application of ionic liquid (IL) for lignocellulose pretreatment has attracted considerable attention. These compounds have been exploited extensively due to their green properties, high thermal stabilities and negligible vapor pressures preventing the release of toxic gases (Wang et al., 2017).

Figure 2 shows the typical lignocellulosic biomass pretreatment by ILs for biofuel production. Table 4 presents a list of ILs generally used for pretreatment of lignocellulosic biomass and Table 5 summarizes the advantages and disadvantages of the IL when used in pretreatment processes. Among the numerous ILs widely utilized for lignocellulose pretreatment are imidazolium-, pyridinium-, [Emim] Ac, $[\mathrm{Emim}] \mathrm{Cl}$ and $[\mathrm{Bmim}] \mathrm{Cl}$. Overall, the ILs recognized effective for cellulose dissolution normally comprise imidazolium+, pyridinium+, ammonium+, phosphonium+, or morpholinium+ based cations and anions. These groups of ILs are found to be effective due to their ability to form strong hydrogen bonds with hydroxyl groups. Through ILbased pretreatment of biomass, lignin and hemicellulose are removed rapidly while the crystalline structure of the cellulose is reduced effectively ( $\mathrm{Li}$ et al., 2010).

In spite of the promising features of ILs, their application at industrial-scale is limited due to the high viscosity of the ILs and the huge amounts of expensive ILs required resulting in high operation cost. $\mathrm{Hu}$ and colleagues managed to overcome the viscosity problem of the ILs by adding water. In their study, 50\% $(\mathrm{w} / \mathrm{w})$ of water was added to the $[\mathrm{Bmim}] \mathrm{BF}_{4} \mathrm{IL}$. They found that through the addition of water in the IL, the enzymatic hydrolysis of the cornstalk was improved by up to $81.68 \%$ (Hu et al., 2018). Integration of methods generally provide promising results. A novel technology of integrating microwave and IL was reported recently (Hou et al., 2019). In this study, the microwaveassisted IL pretreatment of Eucalyptus sawdust led to stronger delignification and deconstruction of the cellulose crystalline structure which subsequently improved enzymatic hydrolysis. Such findings encourage more integration of different pretreatment methods that could enhance biofuels production.

The combination of IL and co-solvents for cellulose dissolution has also
Table 4.

Summary of popular ionic liquid used for pretreatment of lignocellulosic biomass.

\begin{tabular}{|c|c|}
\hline Ionic Liquid & References \\
\hline [Amim]cl (1-allyl-3-methylimidazolium chloride) & $\begin{array}{l}\text { Chen et al. (2017) } \\
\text { Swatloski et al. (2003) }\end{array}$ \\
\hline [Bmim]cl (1-butyl-3-methylimidazolium chloride) & Zhang and Lynd (2004) \\
\hline $\begin{array}{l}{[\mathrm{Hnmp}] \mathrm{Cl}} \\
{[\mathrm{Hnmp}] \mathrm{CH}_{3} \mathrm{SO}_{3}}\end{array}$ & Ma et al. (2016) \\
\hline $\begin{array}{l}\text { Cholinium } \\
\text { 1-Cyano-3-methylimidazolium }\end{array}$ & Ninomiya et al. (2015) \\
\hline 1-(3-Methoxybenzyl)-3-methylimidazolium & Hou et al. (2019) \\
\hline $\begin{array}{l}\text { 1-(3,6-Dioxahexyl)-3-methylimidazolium } \\
\text { 1-Ethyl-3-(3,6-dioxaheptyl)imidazolium }\end{array}$ & \\
\hline 1-(3,6,9-Trioxanonyl)-3-methylimidazolium & \\
\hline 1-Ethyl-3-(3,6,9-trioxadecyl)-imidazolium & \\
\hline 1-Butyl-3-(3,6,9-trioxadecyl)-imidazolium & \\
\hline 1-Ethyl-3-(4,8,12-trioxatridecyl)-imidazolium & \\
\hline 3,3-Ethane-1,2-diylbis(1-methyl-1H-imidazole-3-ium) & Satari et al. (2019) \\
\hline 1-(3,6-Dioxaheptyl)-3-(3,6,9-trioxadecyl)-imidazolium & \\
\hline N-Benzyl-N,N-dimethylammonium & \\
\hline Tetrabutylphosphonium & \\
\hline Trihexyltetradecylphosphonium & \\
\hline N,N-Dimethylathanolammonium & \\
\hline 1,8-Diazabicyclo[5.4.0]undec-7-enium & \\
\hline 1-Butyl-3-methylpyridinium & \\
\hline 1-Butyl-1-methylpyrrolidinium & \\
\hline $\begin{array}{l}\text { 1-Ehyl-3-(3,6,9,12,15,18,21-heptaoxadococyl)- } \\
\text { imidazolium }\end{array}$ & Holm and Lassi (2011) \\
\hline 1-Benzyl-3-methylimidazolium & \\
\hline
\end{tabular}


been acknowledged as an efficient method. It was reported that the co-solvent system has several advantages over the parent ILs that include a high rate of dissolution, high thermal stability, and low viscosity (de Oliveira Santos et al., 2016). In a study conducted by the Rinaldi group, it was discovered that the solvent system comprising of aprotic polar solvents (e.g., N,Ndimethylformamide (DMF), dimethylsulphoxide (DMSO), N,Ndimethylacetamide (DMA), and 1,3-dimethyl-2-imidazolidinone (DMI)) with a minimum molar fraction of IL was capable of achieving high cellulose dissolution at a faster rate and at low temperatures of about $50^{\circ} \mathrm{C}$ contrasting to the application of only IL that required longer time at high temperatures (Rinaldi, 2011). Xu et al. (2013) developed a powerful

cellulose solution by adding DMSO to 1-butyl-3-methylimidazolium acetate $([\mathrm{Bmim}] \mathrm{Ac})$ and greatly enhanced cellulose dissolution. Overall, rational design of ILs and the use of IL-based solvent systems could be regarded as efficient approaches to enhance pretreatment efficiency, increase cellulose dissolution, reduce the cost of ILs, and to improve their compatibility with enzymes.

Table 5.

Advantages and disadvantages of IL application in pretreatment of lignocelluosic biomass.

\begin{tabular}{|c|c|c|}
\hline Advantages & Disadvantages & References \\
\hline $\begin{array}{l}\text { - Increases in biomass } \\
\text { digestibility } \\
\text { - Environmentally } \\
\text { friendly due to low } \\
\text { toxicity } \\
\text { - Low volatility } \\
\text { - Low density } \\
\text { - High thermal and } \\
\text { chemical stability } \\
\text { - Ability to form two- } \\
\text { phase system with } \\
\text { numerous solvents }\end{array}$ & $\begin{array}{l}\text { - Expensive solvents } \\
\text { - High cost for industrial } \\
\text { applications } \\
\text { - May contain several impurities, } \\
\text { such as halides, water and } \\
\text { volatiles. } \\
\text { - Instability of ILs and possible } \\
\text { contaminnnation resulting from the } \\
\text { reactions between ILs and substrate } \\
\text { may make IL reusability unfeasible } \\
\text { - In most cases ionic liquids are } \\
\text { viscous that negatively affect the } \\
\text { mass transfer and power } \\
\text { requirements for mixing } \\
\text { heterogeneous liquid-liquid } \\
\text { systems. }\end{array}$ & $\begin{array}{l}\text { Chen et al. (2017) } \\
\text { Holm and Lassi } \\
\text { (2011) } \\
\text { Ouellet et al. } \\
\text { (2011) }\end{array}$ \\
\hline
\end{tabular}

\subsubsection{Hydrothermal pretreatment}

Over the past decade, hydrothermal processes have played a vital role in the generation of fuels. Hydrothermal pretreatments utilize high temperatures of subcritical water $\left(<374^{\circ} \mathrm{C}\right)$. Such high temperatures are applied to denature plant cell walls, degrade hemicelluloses, and transform lignin into sugars/syngas (Zhang et al., 2012). Hydrothermal-based biomass conversion techniques can be categorized into three main classes depending on the target product: carbonization, liquefaction, and gasification. These categories differ in terms of the process temperature and the type of products yielded. Figure 3 illustrates an overview of the hydrothermal pretreatment. The benefits of hydrothermal application include high energy conversion, low corrosion, and no catalyst requirements (Joelsson et al., 2016). Biomass pretreatment using this technique could enhance the accessibility of cellulose to enzymes by increasing the surface area of the biomass and decreasing the cellulose crystallinity (Binod et al., 2010).

Hydrothermal carbonization process is conducted in temperatures ranging between 200 and $270^{\circ} \mathrm{C}$ and the product is a carbon-rich solid char, whereas hydrothermal liquefaction involves processing conditions between 250 and $400^{\circ} \mathrm{C}$, producing bio-oil, water-soluble constituents, char and a gas phase mainly consisting of carbon dioxide (Toor et al., 2011) Hydrothermal gasification is usually performed at temperatures greater than $400^{\circ} \mathrm{C}$ and the product is fuel gases. Generally, when biomass is exposed to thermal heating, inhibitors and acids are released from the pretreated biomass. These by-products could interfere with the downstream enzymatic hydrolysis. Hence, diverse hydrothermal phases are applied to circumvent these inhibitory compounds, such as steam explosion, steam treatment, and liquid hot water $\left(160-240^{\circ} \mathrm{C}\right)$ (Ruiz et al., 2008). The hydrolysis of lignocellulose biomass and the disruption of lignin structure utilizing subcritical and supercritical water process is influenced by a few operating conditions such as temperature, time of residence, flow rate, pressure, $\mathrm{pH}$, as well as the parameters related to the equipment used (Torres-Mayanga et al., 2019). The extreme temperatures used in hydrothermal gasification lead to greater reaction rates compared to the rates obtained in hydrothermal liquefaction and carbonization. Recently, solvolysis liquefaction which is the addition of organic solvents in the liquefaction process has also been gaining interest. The addition of an organic solvent such as ethanol, methanol, propanol, and butanol in the process is reported to enhance the dissolution and decomposition of biomass, stabilize reaction intermediates, inhabit char formation, and improve bio-oil energy density (Zeb et al., 2017). In a recent study conducted by Xiao and colleagues, they demonstrated that the addition of ethanol in the hydrothermal liquefaction process increased the penetration of solvent into the rigid structure of lignocellulose which subsequently led to high bio-oil yields (Wu et al., 2019).

Although hydrothermal process has been shown to be effective for high bio-oil yields, there are several concerns that need to be addressed to ensure high efficiency of the process. Up to date, the research on hydrothermal pretreatment of biomass for biofuel production is limited to laboratory scale experiments.

This is ascribed to a number of limitations such as the high temperature and pressure conditions involving highly sophisticated equipment, the utilization of reducing gases increasing the process cost, and difficulties in bio-oil extraction due to composition complexity and low yields. In order to improve the process, reduce the operating cost, and enhance bio-oil yield,

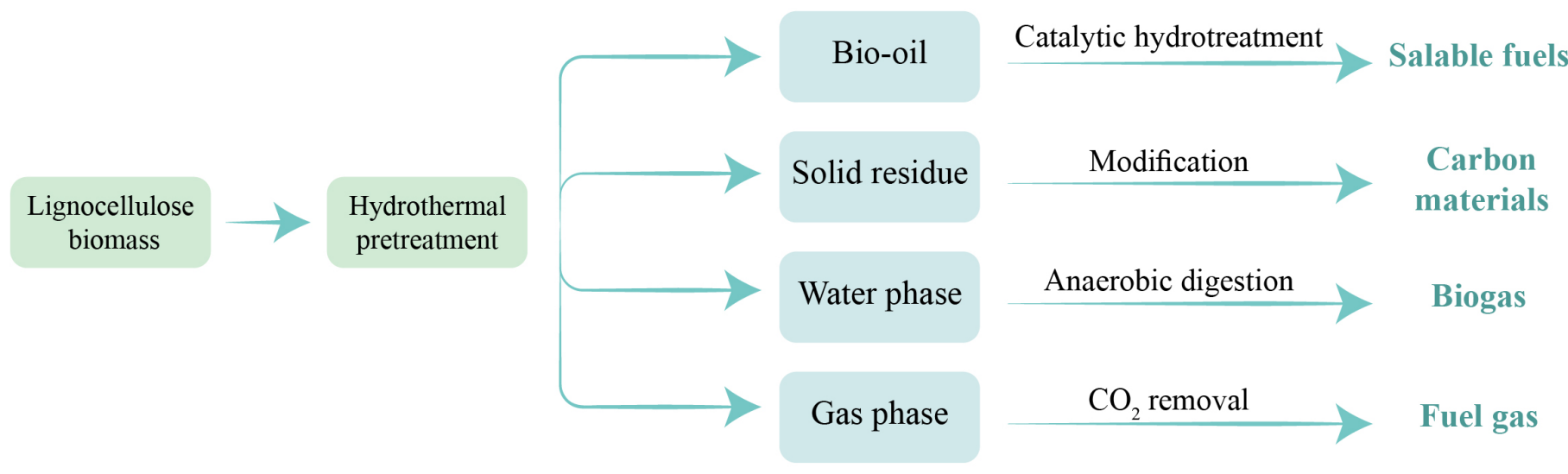

Fig. 3. Overview of lignocellulose hydrothermal pretreatment process. 
there is a need for developing more efficient and economical hydrogen donors to substitute the reducing gas and subsequently lower the reaction cost. In addition, exploration of innovative methods and technologies for bio-oil refining is required to upgrade the oil quality.

\section{Concluding remarks and future prospects}

Lignocellulosic materials are the most abundant feedstock available for second-generation biofuels production and hence, tremendous research efforts have been made to enhance the various aspects of the processes involved (Yau and Easterling, 2018; Raud et al., 2019). However, there are several major challenges hindering the large scale and cost-effective production of cellulosic biofuels (Raud et al., 2019). Many lignocellulosic biofuel plants are under construction while many are already operational in the Europe, North and South America, and Asia (Raud et al., 2019). The biggest difference in capital costs between the first and second generations is attributed to the pretreatment stage. This is ascribed to requirement for reactors capable of resisting high pressures, high temperatures, and/or corrosive catalysts (Stephen et al., 2012). To reduce the cost of the pretreatment process, Eggeman and Elander (2005) studied the economic features of different pretreatment approaches considering both the capital and operating costs as well as glucose and xylose sugar yields. They argued that low-cost reactors are often counterbalanced by the higher costs associated with pretreatment catalyst recovery or higher cost of ethanol product recovery. Moreover, they emphasized that cost reduction evaluation must be performed for each pretreatment as such analysis could help to improve the overall economy of the whole production process by identifying process parameters with the greatest economic impact.

In addition to cost, there are several other factors such as toxicity and waste disposal that need to be addressed prior to the selection of a pretreatment process. Many types of pretreatment require water and organic solvents in at least one stage of the process. This would result in the generation of wastewater which must be remediated to prevent contamination of the environment, while many organic solvents are highly flammable, volatile, and potentially toxic requiring additional safety and storage considerations; all adding to the total cost of the process (Terán Hilares et al., 2018). Besides toxicity and waste disposal, some pretreatment methods involve additional equipment or have high energy requirements which should also be factored into the cost and feasibility of the overall process (Den et al., 2018; Sharma et al., 2019). Many physical/chemical pretreatments utilize acid or alkali solutions or solvents, which would require special corrosion resistant equipment as well as additional maintenance procedures. In general, minimizing solvent cost, minimizing solvent losses, and maximizing biomass loading are critical to reduce the overall operating expenses and to produce a more carbon-neutral product (Chen et al., 2017; Tu and Hallett, 2019).

High sugar yield is also indispensable for the economic production of lowcost lignocellulosic fuels and chemicals (Verardi et al., 2018). Therefore, although conventional hydrothermal pretreatment with hot water is an easy process but it can dramatically increase the overall cost of the whole process in response to the degradation of reducing sugars during the pretreatment, unfermentable oligomer output, and the high quantity of costly enzymes required to achieve satisfactory results from hydrothermal pretreated biomass (de Oliveira Santos et al., 2018; Wang et al., 2018; Yang et al., 2018). On the contrary, advanced hydrothermal pretreatment (based on the biorefinery platform) aimed at generating added value from lignin and other components (currently destined for energy production), could to some extent address the above-mentioned shortcomings. Technically, by moving water through a fixed bed of lignocellulose biomass, extremely high hemicellulose sugar yields could be obtained, the majority of lignin could be recovered, and sugar release from the pretreated solids could be enhanced with lower enzyme loadings.

The intensive capital investment required is also among the major reasons to the high production cost of lignocellulosic biofuels. Based on a study, it was predicted that simultaneous saccharification process accounted for $15 \%$ of the overall production cost, whereas pretreatment accounted for $17 \%$ of the production cost (Tsegaye et al., 2019). Currently, most of the reports available in the literature were performed at lab scale and there is limited information on the real-world production cost arising from all the stages involved in biofuel production from lignocellulosic biomass, i.e., delignification, hydrolysis, and fermentation. Therefore, future research works should be devoted to the optimization of operating parameters and assessment of total cost of biofuel production from lignocellulose biomass at large scale by using different pretreatment methods. Such information would pave the way for industrialscale lignocellulosic biofuels production.

Last but not the least, more research should be directed toward the identification/isolation of more effective lignin hydrolyzing microbes by taking advantage of advanced molecular techniques.

\section{Acknowledgments}

This work was supported by the Fundamental Research Grant Scheme, Malaysia [FRGS/1/2019/STG05/UNIM/02/2].

\section{References}

[1] Alio, M.A., Tugui, O.C., Vial, C., Pons, A., 2019. Microwaveassisted Organosolv pretreatment of a sawmill mixed feedstock for bioethanol production in a wood biorefinery. Bioresour. Technol. 276, 170-176.

[2] Amin, F.R., Khalid, H., Zhang, H., u Rahman, S., Zhang, R., Liu, G., Chen, C., 2017. Pretreatment methods of lignocellulosic biomass for anaerobic digestion. AMB Express. 7(1), 72.

[3] Arora, A., Priya, S., Sharma, P., Sharma, S., Nain, L., 2016. Evaluating biological pretreatment as a feasible methodology for ethanol production from paddy straw. Biocatal. Agric. Biotechnol. 8 , 66-72.

[4] Baruah, J., Nath, B.K., Sharma, R., Kumar, S., Deka, R.C., Baruah, D.C., Kalita, E., 2018. Recent trends in the pretreatment of lignocellulosic biomass for value-added products. Front. Energy Res. 6,141

[5] Binod, P., Sindhu, R., Singhania, R.R., Vikram, S., Devi, L., Nagalakshmi, S., Kurien, N., Sukumaran, R.K., Pandey, A., 2010 Bioethanol production from rice straw: an overview. Bioresour. Technol. 101(13), 4767-4774

[6] Branco, R.H., Serafim, L.S., Xavier, A.M., 2019. Second generation bioethanol production: on the use of pulp and paper industry wastes as feedstock. Ferment. 5(1), 4 .

[7] Bussemaker, M.J., Zhang, D., 2013. Effect of ultrasound on lignocellulosic biomass as a pretreatment for biorefinery and biofuel applications. Ind. Eng. Chem. Res. 52(10), 3563-3580.

[8] Cardona, E., Llano, B., Peñuela, M., Peña, J., Rios, L.A., 2018. Liquid-hot-water pretreatment of palm-oil residues for ethano production: an economic approach to the selection of the processing conditions. Energy. 160, 441-451

[9] Cheah, W.Y., Show, P.L., Chang, J.S., Ling, T.C., Juan, J.C., 2015 Biosequestration of atmospheric $\mathrm{CO}_{2}$ and flue gas-containing $\mathrm{CO}_{2}$ by microalgae. Bioresour. Technol. 184, 190-201.

[10] Cheah, W.Y., Ling, T.C., Show, P.L., Juan, J.C., Chang, J.S., Lee, D.J., 2016a. Cultivation in wastewaters for energy: a microalgae platform. Appl. Energy. 179, 609-625.

[11] Cheah, W.Y., Ling, T.C., Juan, J.C., Lee, D.J., Chang, J.S., Show, P.L., 2016b. Biorefineries of carbon dioxide: from carbon capture and storage (CCS) to bioenergies production. Bioresour. Technol. 215 346-356

[12] Chen, H., Liu, J., Chang, X., Chen, D., Xue, Y., Liu, P., Lin, H., Han, S., 2017. A review on the pretreatment of lignocellulose for high value chemicals. Fuel Process. Technol. 160, 196-206.

[13] da Silva, A.R.G., Ortega, C.E.T., Rong, B.G., 2016. Technoeconomic analysis of different pretreatment processes for lignocellulosic-based bioethanol production. Bioresour. Technol. 218, 561-570.

[14] de Oliveira Santos, V.T., Siqueira, G., Milagres, A.M.F., Ferraz, A. 2018. Role of hemicellulose removal during dilute acid pretreatment on the cellulose accessibility and enzymatic hydrolysis of compositionally diverse sugarcane hybrids. Ind. Crops Prod. 111 722-730.

[15] Den, W., Sharma, V.K., Lee, M., Nadadur, G., Varma, R.S., 2018. Lignocellulosic biomass transformations via greener oxidative pretreatment processes: access to energy and value-added chemicals. Front. Chem. 6. 
[16] Devarapalli, M., Atiyeh, H.K., 2015. A review of conversion processes for bioethanol production with a focus on syngas fermentation. Biofuel Res. J. 2(3), 268-280.

[17] Devi, J., Deb, U., Barman, S., Das, S., Bhattacharya, S.S., Tsang, Y.F., Lee, J.H., Kim, K.H., 2019. Appraisal of lignocellusoic biomass degrading potential of three earthworm species using vermireactor mediated with spent mushroom substrate: compost quality, crystallinity, and microbial community structural analysis. Sci. Total Environ. 135215

[18] Eggeman, T., Elander, R.T., 2005. Process and economic analysis of pretreatment technologies. Bioresour. Technol. 96(18), 2019-2025.

[19] El Achkar, J.H., Lendormi, T., Salameh, D., Louka, N., Maroun, R.G., Lanoisellé, J.L., Hobaika, Z., 2018. Influence of pretreatment conditions on lignocellulosic fractions and methane production from grape pomace. Bioresour. Technol. 247, 881-889.

[20] Fatriasari, W., Fajriutami, T., Laksana, R.B., Wistara, N.J., 2019. Microwave assisted-acid hydrolysis of jabon kraft pulp. Waste Biomass Valorization. 10(6), 1503-1517.

[21] Goshadrou, A., 2019. Bioethanol production from Cogongrass by sequential recycling of black liquor and wastewater in a mild-alkali pretreatment. Fuel. 258, 116141.

[22] Gu, B.J., Wang, J., Wolcott, M.P., Ganjyal, G.M., 2018. Increased sugar yield from pre-milled Douglas-fir forest residuals with lower 1energy consumption by using planetary ball milling. Bioresour. Technol. 251, 93-98.

[23] Heaton, E.A., Dohleman, F.G., Long, S.P., 2008. Meeting US biofuel goals with less land: the potential of Miscanthus. Global Change Biol. 14(9), 2000-2014.

[24] Holm, J., Lassi, U., 2011. Ionic liquids in the pretreatment of lignocellulosic biomass. Rijeka, Croatia: Intech Open Access Publisher.

[25] Hou, X., Wang, Z., Sun, J., Li, M., Wang, S., Chen, K., Gao, Z., 2019. A microwave-assisted aqueous ionic liquid pretreatment to enhance enzymatic hydrolysis of Eucalyptus and its mechanism. Bioresour. Technol. 272, 99-104.

[26] Hu, X., Cheng, L., Gu, Z., Hong, Y., Li, Z., Li, C., 2018. Effects of ionic liquid/water mixture pretreatment on the composition, the structure and the enzymatic hydrolysis of corn stalk. Ind. Crops Prod. 122, 142-147.

[27] Jędrzejczyk, M., Soszka, E., Czapnik, M., Ruppert, A.M., Grams, J., 2019. Chapter 6- Physical and chemical pretreatment of lignocellulosic biomass. Second Third Gener Feedstocks. Elsevier. 143-196.

[28] Joelsson, E., Erdei, B., Galbe, M., Wallberg, O., 2016. Techno-economic evaluation of integrated first-and second-generation ethanol production from grain and straw. Biotechnol. Biofuels. 9(1), 1.

[29] Karunanithy, C., Muthukumarappan, K., Gibbons, W.R., 2012. Effect of extruder screw speed, temperature, and enzyme levels on sugar recovery from different biomasses. ISRN Biotechnol. 2013.

[30] Kim, J.W., Kim, K.S., Lee, J.S., Park, S.M., Cho, H.Y., Park, J.C., Kim, J.S., 2011. Two-stage pretreatment of rice straw using aqueous ammonia and dilute acid. Bioresour. Technol. 102(19), 8992-8999.

[31] Kim, D., 2018. Physico-chemical conversion of lignocellulose: inhibitor effects and detoxification strategies: a mini review. Molecules. 23(2), 309.

[32] Koupaie, E.H., Dahadha, S., Lakeh, A.B., Azizi, A., Elbeshbishy, E., 2019. Enzymatic pretreatment of lignocellulosic biomass for enhanced biomethane production-a review. J. Environ. Manage. 233, 774-784.

[33] Kumar, A.K., Sharma, S., 2017. Recent updates on different methods of pretreatment of lignocellulosic feedstocks: a review. Bioresour. Bioprocess. 4(1), 7 .

[34] Kumar, A., Singh, J., Baskar, C., 2019. Lignocellulosic biomass for bioethanol production through microbes: strategies to improve process efficiency. Prospects Renew. Bioprocess. Future Energy Syst. Springer, Cham. 357-386

[35] Kumar, M.N., Ravikumar, R., Thenmozhi, S., Kumar, M.R., Shankar, M.K., 2019. Choice of pretreatment technology for sustainable production of bioethanol from lignocellulosic biomass: bottle necks and recommendations. Waste Biomass Valori. 10(6), 1693-1709.

[36] Kumar, R., Tabatabaei, M., Karimi, K., Sárvári Horváth, I., 2016. Recent updates on lignocellulosic biomass derived ethanol-a review. Biofuel Res. J. 3(1), 347-356.

[37] Li, C., Knierim, B., Manisseri, C., Arora, R., Scheller, H.V., Auer, M., Vogel, K.P., Simmons, B.A., Singh, S., 2010. Comparison of dilute acid and ionic liquid pretreatment of switchgrass: biomass recalcitrance, delignification and enzymatic saccharification. Bioresour. Technol. 101, 4900-4906.

[38] Liang, S., Gu, H., Bergman, R.D., 2017. Life cycle assessment of cellulosic ethanol and biomethane production from forest residues. BioResources. 12(4), 7873-7883.

[39] Liyamen, A., Ricke, S.C., 2012. Lignocellulosic biomass for bioethanol production: current perspectives, potential issues and future prospects. Prog. Energy Combust.38(4), 449-467.

[40] Liu, Y., Luo, P., Xu, Q.Q., Wang, E.J., Yin, J.Z., 2014. Investigation of the effect of supercritical carbon dioxide pretreatment on reducing sugar yield of lignocellulose hydrolysis. Cell. Chem. Technol. 48, 8995.

[41] Longati, A.A., Lino, A.R., Giordano, R.C., Furlan, F.F., Cruz, A.J. 2018. Defining research \& development process targets through retrotechno-economic analysis: the sugarcane biorefinery case. Bioresour. Technol. 263, 1-9.

[42] Lü, H., Ren, M., Zhang, M., Chen, Y., 2013. Pretreatment of corn stover using supercritical $\mathrm{CO}_{2}$ with water-ethanol as cosolvent. Chinese J. Chem. Eng. 21(5), 551-557.

[43] Ma, H.H., Zhang, B.X., Zhang, P., Li, S., Gao, Y.F., Hu, X.M., 2016 An efficient process for lignin extraction and enzymatic hydrolysis of corn stalk by pyrrolidonium ionic liquids. Fuel Process. Technol. 148, $138-145$

[44] Matsakas, L., Kekos, D., Loizidou, M., Christakopoulos, P., 2014 Utilization of household food waste for the production of ethanol at high dry material content. Biotechnol. Biofuels. 7(1), 4.

[45] Maurya, D.P., Singla, A., Negi, S., 2015. An overview of key pretreatment processes for biological conversion of lignocellulosic biomass to bioethanol. 3 Biotech. 5(5), 597-609.

[46] Menon, V., Rao, M., 2012. Trends in bioconversion of lignocellulose: biofuels, platform chemicals \& biorefinery concept. Prog. Energy Combust. 38(4), 522-550.

[47] Mu, D., Seager, T., Rao, P.S., Zhao, F., 2010. Comparative life cycle assessment of lignocellulosic ethanol production: biochemical versus thermochemical conversion. J. Environ. Manage. 46(4), 565-578.

[48] Nikolić, S., Mojović, L., Rakin, M., Pejin, D., Pejin, J., 2011 Utilization of microwave and ultrasound pretreatments in the production of bioethanol from corn. Clean Technol. Environ. Policy. 13(4), 587-594.

[49] Ninomiya, K., Kohori, A., Tatsumi, M., Osawa, K., Endo, T. Kakuchi, R., Ogino, C., Shimizu, N., Takahashi, K., 2015. Ionic liquid/ultrasound pretreatment and in situ enzymatic saccharification of bagasse using biocompatible cholinium ionic liquid. Bioresour. Technol. 176, 169-174.

[50] Ouellet, M., Datta, S., Dibble, D.C., Tamrakar, P.R., Benke, P.I., Li, C., Singh, S., Sale, K.L., Adams, P.D., Keasling, J.D., Simmons, B.A., 2011. Impact of ionic liquid pretreated plant biomass on Saccharomyces cerevisiae growth and biofuel production. Green Chem. 13(10), 2743-2749.

[51] Paul, S., Dutta, A., 2018. Challenges and opportunities of lignocellulosic biomass for anaerobic digestion. Resour. Conserv. Recycl. 130, 164-174.

[52] Prasad, A., Sotenko, M., Blenkinsopp, T., Coles, S.R., 2016. Life cycle assessment of lignocellulosic biomass pretreatment methods in biofuel production. Int. J. Life Cycle Assess. 21(1), 44-50.

[53] Puri, V.P., Mamers, H., 1983. Explosive pretreatment of lignocellulosic residues with high-pressure carbon dioxide for the production of fermentation substrates. Biotechnol. Bioeng. 25(12), 3149-3161

[54] Raud, M., Kikas, T., Sippula, O., Shurpali, N.J., 2019. Potentials and challenges in lignocellulosic biofuel production technology. Renew. Sust. Energy Rev. 111, 44-56.

[55] Rinaldi, R., 2011. Instantaneous dissolution of cellulose in organic electrolyte solutions. Chem. Commun. 47(1), 511-513. 
[56] Rooni, V., Raud, M., Kikas, T., 2017. The freezing pre-treatment of lignocellulosic material: a cheap alternative for Nordic countries. Energy. 139, 1-7.

[57] Rosales-Calderon, O., Arantes, V., 2019. A review on commercial-scale high-value products that can be produced alongside cellulosic ethanol. Biotechnol. Biofuels. 12(1), 240.

[58] Ruiz, E., Cara, C., Manzanares, P., Ballesteros, M., Castro, E., 2008. Evaluation of steam explosion pre-treatment for enzymatic hydrolysis of sunflower stalks. Enzyme Microb. Technol. 42, 160-166.

[59] Sarkar, N., Ghosh, S.K., Bannerjee, S., Aikat, K., 2012. Bioethanol production from agricultural wastes: an overview. Renew. Energy. 37(1), $19-27$

[60] Safarian, S., Unnthorsson, R., 2018. An assessment of the sustainability of lignocellulosic bioethanol production from wastes in Iceland. Energies. 11(6), 1493

[61] Saha, B.C., Kennedy, G.J., Qureshi, N., Cotta, M.A., 2017. Biological pretreatment of corn stover with NRRL-13108 for enhanced enzymatic hydrolysis and efficient ethanol production. Biotechnol. Progr.

[62] Satari, B., Karimi, K., Kumar, R., 2019. Cellulose solvent-based pretreatment for enhanced second-generation biofuel production: a review. Sust. Energy Fuels. 3(1), 11-62.

[63] Sathendra, E.R., Baskar, G., Praveenkumar, R., Gnansounou, E., 2019. Bioethanol production from palm wood using Trichoderma reesei and Kluveromyces marxianus. Bioresour. Technol. 271, 345-352.

[64] Scagline-Mellor, S., Griggs, T., Skousen, J., Wolfrum, E., Holásková, I., 2018. Switchgrass and giant miscanthus biomass and theoretical ethanol production from reclaimed mine lands. Bioenergy Res. 11(3), 562-573.

[65] Sharma, N., Sharma, N., 2017. Microbial xylanases and their industrial applications as well as future perspectives: a review. Global J. Biol. Agric. Health Sci. 6, 5-12.

[66] Sharma, H.K., Xu, C., Qin, W., 2019. Biological pretreatment of lignocellulosic biomass for biofuels and bioproducts: an overview. Waste Biomass Valori. 10(2), 235-251.

[67] Shimizu, F.L., Monteiro, P.Q., Ghiraldi, P.H.C., Melati, R.B., Pagnocca, F.C., de Souza, W., Sant'Anna, C., Brienzo, M., 2018. Acid, alkali and peroxide pretreatments increase the cellulose accessibility and glucose yield of banana pseudostem. Ind. Crops Prod. 115, 62-68.

[68] Singh, J.K., Vyas, P., Dubey, A., Upadhyaya, C.P., Kothari, R., Tyagi, V.V., Kumar, A., 2018. Assessment of different pretreatment technologies for efficient bioconversion of lignocellulose to ethanol. Front. Biosci, 10, 350-371.

[69] Smuga-Kogut, M., Piskier, T., Walendzik, B., SzymanowskaPowałowska, D., 2019. Assessment of wasteland derived biomass for bioethanol production. Electron. J. Biotechn. 41, 1-8.

[70] Solarte-Toro, J.C., Romero-García, J.M., Martínez-Patiño, J.C., RuizRamos, E., Castro-Galiano, E., Cardona-Alzate, C.A., 2019. Acid pretreatment of lignocellulosic biomass for energy vectors production: a review focused on operational conditions and techno-economic assessment for bioethanol production. Renew. Sust. Energy Rev. 107, 587-601.

[71] Stephen, J.D., Mabee, W.E., Saddler, J.N., 2012. Will second-generation ethanol be able to compete with first-generation ethanol? opportunities for cost reduction. Biofuel Bioprod. Biorefin. 6(2), 159-176.

[72] Swatloski, R.P., Holbrey, J.D., Rogers, R.D., 2003. Ionic liquids are not always green: hydrolysis of 1-butyl-3-methylimidazolium hexafluorophosphate. Green Chem. 5(4), 361-363.

[73] Santos, J.C.D., 2018. Hydrodynamic cavitation as a strategy to enhance the efficiency of lignocellulosic biomass pretreatment. Crit. Rev. Biotechnol. 38(4), 483-493.

[74] Toor, S.S., Rosendahl, L., Rudolf, A., 2011. Hydrothermal liquefaction of biomass: a review of subcritical water technologies. Energy. 36, 23282342 .

[75] Torres-Mayanga, P.C., Lachos-Perez, D., Mudhoo, A., Kumar, S., Brown, A.B., Tyufekchiev, M., Dragone, G., Mussatto, S.I., Rostagno, M.A., Timko, M., Forster-Carneiro, T., 2019. Production of biofuel precursors and value-added chemicals from hydrolysates resulting from hydrothermal processing of biomass: a review. Biomass Bioenergy. 130, 105397
[76] Tsegaye, B., Balomajumder, C., Roy, P., 2019. Microbial delignification and hydrolysis of lignocellulosic biomass to enhance biofuel production: an overview and future prospect. Bull. National Res. Centre. 43(1), 51.

[77] Tran, T.T.A., Le, T.K.P., Mai, T.P., Nguyen, D.Q., 2019. Bioethano Production from Lignocellulosic Biomass. In Alcohol Fuels-Current Technologies and Future Prospect. IntechOpen.

[78] Trincone, A., 2018. Update on marine carbohydrate hydrolyzing enzymes: biotechnological applications. Molecules. 23(4), 901.

[79] Tu, W.C., Hallett, J.P., 2019. Recent advances in the Pretreatment of Lignocellulosic Biomass. Curr. Opin. Green Sust. Chem. 20, 11-17.

[80] Varelas, V., Langton, M., 2017. Forest biomass waste as a potential innovative source for rearing edible insects for food and feed-a review. Innovative food Sci. Emerg. Technol. Innovative. 41, 193 205.

[81] Vasco-Correa, J., Ge, X., Li, Y., 2016. Biological pretreatment of lignocellulosic biomass, in: Mussatto, S.I. (Ed.), Biomass fractionation technologies for a lignocellulosic feedstock based biorefinery. Elsevier. 561-585

[82] Vasco-Correa, J., Luo, X., Li, Y., Shah, A., 2019. Comparative study of changes in composition and structure during sequential fungal pretreatment of non-sterile lignocellulosic feedstocks. Ind. Crops Prod. 133, 383-394.

[83] Verardi, A., Blasi, A., Marino, T., Molino, A., Calabrò, V., 2018. Effect of steam-pretreatment combined with hydrogen peroxide on lignocellulosic agricultural wastes for bioethanol production: analysis of derived sugars and other by-products. J. Energy Chem. 27(2), 535543.

[84] Waghmare, P.R., Khandare, R.V., Jeon, B.H., Govindwar, S.P., 2018 Enzymatic hydrolysis of biologically pretreated sorghum husk for bioethanol production. Biofuel Res. J. 5(3), 846-853.

[85] Wang, X., Ruan, Z., Sheridan, P., Boileau, D., Liu, Y., Liao, W., 2015. Two-stage photoautotrophic cultivation to improve carbohydrate production in Chlamydomonas reinhardtii. Biomass Bioenergy. 74, 280-287.

[86] Wang, Y., Guo, W., Cheng, C.L., Ho, S.H., Chang, J.S., Ren, N., 2016. Enhancing bio-butanol production from biomass of Chlorella vulgaris JSC-6 with sequential alkali pretreatment and acid hydrolysis. Bioresour. Technol. 200, 557-564.

[87] Wang, F.L., Li, S., Sun, Y.X., Han, H.Y., Zhang, B.X., Hu, B.Z. Gao, Y.F., Hu, X.M., 2017. Ionic liquids as efficient pretreatment solvents for lignocellulosic biomass. RSC Adv. 7, 47990-47998.

[88] Wang, D., Shen, F., Yang, G., Zhang, Y., Deng, S., Zhang, J., Zeng, Y., Luo, T., Mei, Z., 2018. Can hydrothermal pretreatment improve anaerobic digestion for biogas from lignocellulosic biomass? Bioresour. Technol. 249, 117-124.

[89] Wu, X.F., Yin, S.S., Zhou, Q., Li, M.F., Peng, F., Xiao, X., 2019 Subcritical liquefaction of lignocellulose for the production of biooils in ethanol/water system. Renew. Energy. 136, 865-872.

[90] Xu, A., Zhang, Y., Zhao, Y., Wang, J., 2013. Cellulose dissolution at ambient temperature: Role of preferential solvation of cations of ionic liquids by a cosolvent. Carbohydr. Polym. 92(1), 540-544.

[91] Xu, X., Xu, Z., Shi, S., Lin, M., 2017. Lignocellulose degradation patterns, structural changes, and enzyme secretion by Inonotu. obliquus on straw biomass under submerged fermentation. Bioresour. Technol. 241, 415-423.

[92] Yang, B., Tao, L., Wyman, C.E., 2018. Strengths, challenges, and opportunities for hydrothermal pretreatment in lignocellulosic biorefineries. Biofuels, Bioprod. Biorefin. 12(1), 125-138.

[93] Yao, Y., Bergeron, A.D., Davaritouchaee, M., 2018. Methane recovery from anaerobic digestion of urea-pretreated wheat straw. Renew. Energy. 115, 139-148.

[94] Yau, Y.Y., Easterling, M., 2018. Lignocellulosic Feedstock Improvement for Biofuel Production Through Conventional Breeding and Biotechnology. In Biofuels: Greenhouse Gas Mitigation and Global Warming. Springer, New Delhi. 107-140.

[95] Zabed, H., Sahu, J.N., Boyce, AN., Faruq, G., 2016. Fuel ethanol production from lignocellulosic biomass: an overview on feedstocks 
and technological approaches. Renew. Sust. Energy Rev. 66, 751-774.

[96] Zakaria, M.R., Fujimoto, S., Hirata, S., Hassan, M.A., 2014. Ball milling pretreatment of oil palm biomass for enhancing enzymatic hydrolysis, Appl. Biochem. Biotechnol. 173(7), 1778-1789.

[97] Zeb, H., Choi, J., Kim, Y., Kim, J., 2017. A new role of supercritical ethanol in macroalgae liquefaction (Saccharina japonica): Understanding ethanol participation, yield, and energy efficiency. Energy. 118, 116-126.

[98] Zhang, Y.H.P., Lynd, L.R., 2004. Toward an aggregated understanding of enzymatic hydrolysis of cellulose: noncomplexed cellulase systems. Biotechnol. Bioeng. 88(7), 797-824.
[99] Zhang, Y., Fu, X., Chen, H., 2012. Pretreatment based on two-step steam explosion combined with an intermediate separation of fiber cells-optimization of fermentation of corn straw hydrolysates. Bioresour. Technol. 121, 100-104.

[100] Zhang, H., Zhang, P., Ye, J., Wu, Y., Liu, J., Fang, W., Xu, D., Wang, B., Yan, L., Zeng, G., 2018. Comparison of various pretreatments for ethanol production enhancement from solid residue after rumen fluid digestion of rice straw. Bioresour. Technol. 247, 147-156.

[101] Zheng, J., Choo, K., Bradt, C., Lehoux, R., Rehmann, L., 2014 Enzymatic hydrolysis of steam exploded corncob residues after pretreatment in a twin-screw extruder. Biotechnol. Rep. 3, 99-107. 